\title{
Perceptions of Local People toward Community Development and Forest Conservation in Bangladesh: The Case of Sal Forests
}

\author{
Mohammad Abdullah Al Faruq*1, Sourovi Zaman*2 and Masato Katoh*1
}

\begin{abstract}
During the last few decades, forest resources in most developing countries have declined alarmingly, due to extreme pressure from population and poverty. Bangladesh has lost most of its forests during the last 40 years. Nevertheless, degradation of forest remains a matter of concern, emphasizing the fact that effective conservation of natural resources is possible only with an understanding of the attitudes and perceptions of local community. Community involvement in forest management, a relatively new practice in Bangladesh, was initiated with the dual purpose of limiting forest degradation and enhancing community development. In Bangladesh, many forestry projects have been introduced to manage forest resources involving local communities, although few of them have been sustained. The Forest Department of Bangladesh has implemented a program to conserve forests, by improving the livelihoods of people dependent on forests in the Madhupur Sal area. This study examined the perceptions of local people toward community development and forest conservation, and further analyzed factors that present the changing trends in forest conservation and livelihoods in and around forested areas. We conducted a household survey in the forestry project, surveying 200 community forest workers (CFWs). The CFWs were randomly selected and interviewed, and we analyzed human, physical, financial, natural, and social livelihood capitals. The forest conservation program improved the livelihoods of the local community. The perceptions of the community about the general conditions of the forests, and attitudes of the local population about forest conservation, were improved. Dependence on the forests has also noticeably declined during the last few years. An additional outcome of the management program was empowerment and increased dignity of female participants. Such improvements would likely lead to improvements in livelihoods, as well as more sustainable forest management and conservation.
\end{abstract}

keyword: Forest conservation, community development, participatory management, Sal forest, Bangladesh

\section{INTRODUCTION}

Forests serve as important sources of water, food, shelter, medicine, fuel wood, fodder, and timber for local

Affiliations and addresses of the authors:

${ }^{* 1}$ Institute of Mountain Science, Faculty of Agriculture, Shinshu University 8304, Minamiminowa-vill, Kamiina-Dist., Nagano Prefecture, 399-4598, Japan

*2 Assistant professor, Shahid Akbar Ali Science \& Technology College, Baliadangi, Thakurgaon, Bangladesh

Corresponding author: Mohammad Abdullah Al Faruq Postal Address: Institute of Mountain Science, Faculty of Agriculture, Shinshu University 8304, Minamiminowa-vill, Kamiina-Dist., Nagano Prefecture, 399-4598, Japan

Tel: $+81-265-77-1642$

E-Mail: faruq1010@yahoo.com people and adjacent communities. They also provide a wide range of environmental services, including biodiversity conservation, watershed protection, soil protection, and global climate change mitigation (Landell-Mills and Porras, 2002). However, losses of forests and tree diversity have increased globally at unprecedented rates (Kaimowitz and Angelsen, 1998). In developing countries, the degradation of forests has become very severe (Panta et al., 2008; Pelletier et al., 2010).

People in most of the developing world depend on forests for their livelihood. In the case of a developing country such as Bangladesh, the livelihoods of many depend on forests, in terms of direct and indirect income, ecotourism, and the collection and sale of wood and non-wood products. However, in many cases, access to natural resources is not uniform within and between communities (Shackleton et al., 2007). Many local people living in and around forests face high levels of poverty, with limited work opportunities (Shackletom et al., 2007). However, sustainable use of forest resources could provide an opportunity to integrate conservation and social development objectives (Sunderlin et al., 2005). 
Review of Sal forest

Among the wooded tracts in Bangladesh, the Madhupur Sal forests are located in the greater Mymensingh and Tangail districts, also known as Madhupur Grath (Rahman, 2003). Sal forests are considered environmentally and economically important (Alam et al., 2008). Sal forest is the third largest forest ecosystem in Bangladesh (BFD, 2011), covering an area of about 0.12 million ha representing $4.7 \%$ of the total wooded area of the country (GOB, 2010).

Sal forests are surrounded by dense populations that include ethnic minorities. They have functioned for centuries as homelands for ethnic communities such as the Garo and Koch (Ahmed, 2008). The once-biodiversity-rich Madhupur Sal forest has been degrading since 1950. Thousands of people have become directly and indirectly dependent on this forest, placing it under severe pressure in recent decades from illegal logging and clearing for agriculture and industrialization, among other threats (BFD, 2004). In addition, sal trees have higher economic potential due to longer durability compared to other tree species. These pressures have caused significant changes in the forests and associated resources, severely depleting Sal forests. Such exploitation, combined with inappropriate management, has made the current use of forest resources unsustainable (Iftekhar, 2006). Recently published statistics have shown that only $30.1 \%$ of the original Madhupur Sal forest remains intact (Faruq et al., 2016) (Fig. 1).

Review of forestry project

In many developing countries, the management of natural resources has gradually become participatory and typically involves a broad range of stakeholders (Turyahabwe et al., 2012). The Forest Department (FD) of Bangladesh started people-oriented forestry programs in the 1980s, when conservation of degraded Sal forests became a top priority (Muhammed et al., 2008; GOB, 2010). Previous projects failed, due to a shortage of funds and lack of proper implementation plans, as identified by the FD (Nath and Inoue, 2008).

In Bangladesh, the latest forest policy established in 1994 provided general direction rather than legislation to regulate realistic issues such as land tenure, sharing benefits, and market processes (Ahmed, 2008). The local populations in and around forests have important and long-standing relationships with their forests. Hence, their needs, aspirations, and attitudes should be considered in forest management; otherwise, the long-term survival of forested areas will be jeopardized (McNeely, 1990).

To this end, the FD launched a new project entitled "Revegetation of Madhupur Forest through Rehabilitation of Forest-Dependent Local and Ethnic Communities," with the broad aim of protecting forests, sharing resource management among forest communities, and ensuring secure livelihoods for those dependent on forests.

The initial 3-year project was initiated in 2010, but was extended to 2015 . The FD policy was to identify people who were involved in illegal tree felling, provide motivation and training, and transform the population into guardians of the forest, as CFWs (Community Forest Worker), working in parallel with forest staff. We investigated the conservation of the Madhupur Sal forests, the attitudes of the people dependent on them, and the impact of the project on their livelihoods.

\section{METHODOLOGY}

Study site

The Madhupur deciduous Sal forest $\left(24^{\circ} 32^{\prime}-24^{\circ} 47^{\prime} \mathrm{N}, 89^{\circ}\right.$ $\left.59^{\prime}-90^{\circ} 11^{\prime} \mathrm{E}\right)$, the major such forest in Bangladesh, covered an area of approximately 25,495.9 ha in 1982 (Islam and Sato, 2012). The study involved the entire area covered by the project. A large portion of the forest (approximately 8499 ha) was given protected status in 1982, when the reserve was renamed the Madhupur National Park.

The Park is located in the northeastern section of the Tangail Forest Division, a small segment that runs along the boundary of the Mymensingh Forest Division (Fig. 2). The forest is divided into four beats (small administrative units of the FD), namely, Jatyo Uddyan, Dokhola, Aronkhola, and Madhupur. The forest is located approximately $20 \mathrm{~m}$ above sea level. The mean annual rainfall is $2000-2300 \mathrm{~mm}$, and the

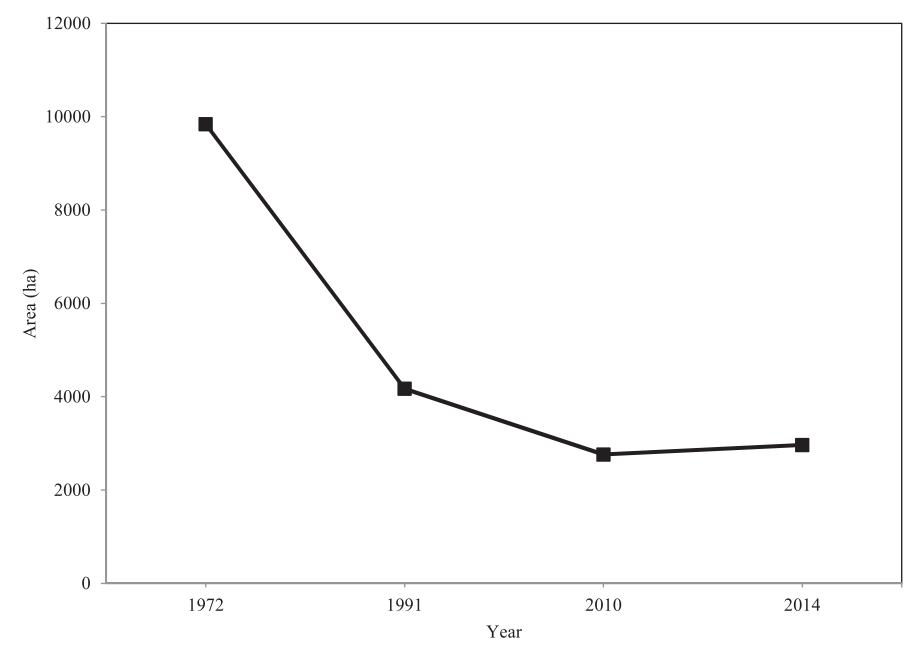

Fig. 1 Changes in Sal forest cover over time in Madhupur (Source: Faruq et al. 2016) 


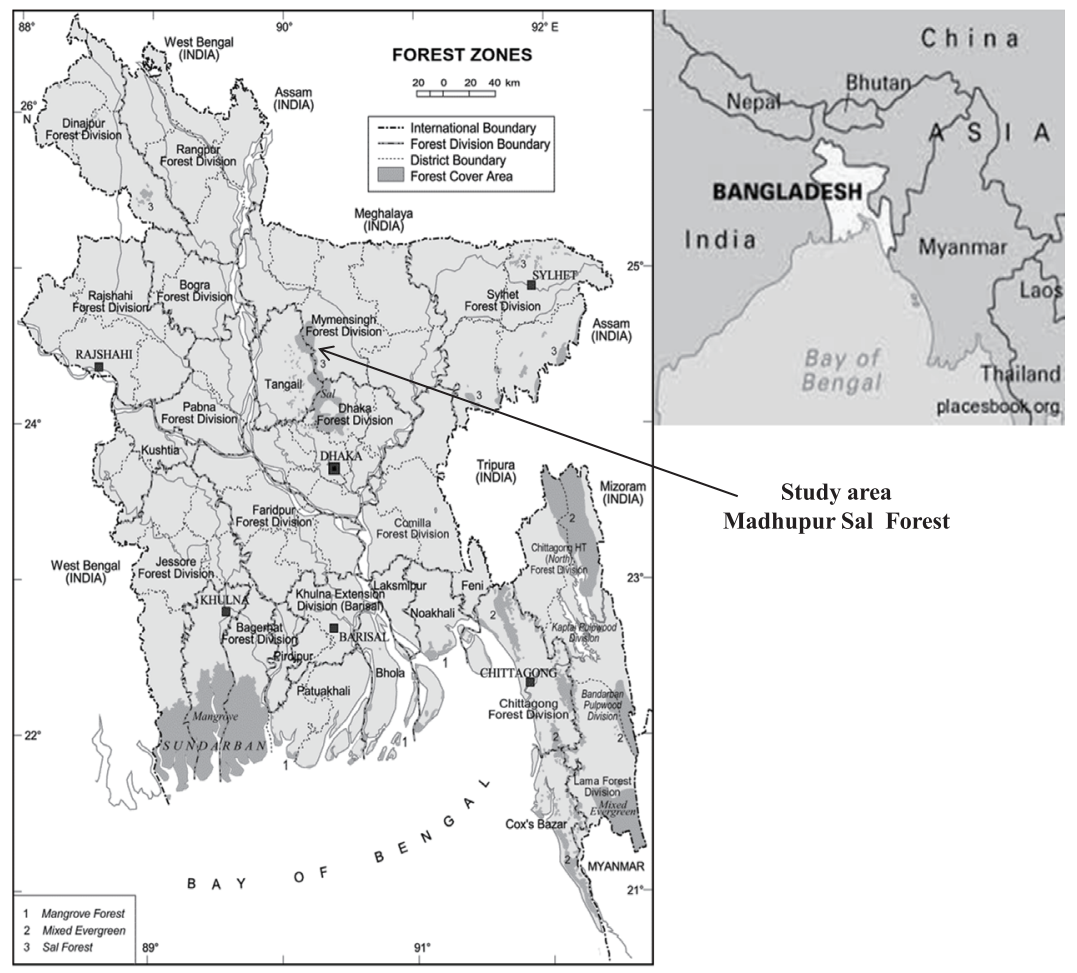

Fig. 2 Location of study site

mean annual temperature is $26.3^{\circ} \mathrm{C}$ (Rahman, 2003).

The Madhupur Sal forest, commonly known as the Madhupur Garh, is on a tract of land approximately $1-2 \mathrm{~m}$ higher than the surrounding plains. The ridges, known locally as Chala, are covered with forest formations and are not continuous. The forest is dense in some parts and sparse in others. Scrub jungle can also be found on the ridges.

The Madhupur Sal forest area has been subjected to some degree of exploitation. Many animal species (e.g., tiger, leopard, elephant, sloth bear, and spotted deer) have gone extinct, although much plant diversity still exists (NSP, 2008). The height of the forest canopy varies between 10 and $30 \mathrm{~m}$. The dominant species $(80-100 \%$ of trees) is the commercially profitable Sal tree (Shorea robusta), which dominates the upper canopy. It is associated with Ajuli (Dillenia jpentagyna), Amlaki (Phyllanthus emblica), Koroi (Albizia procera), Terminalia sp, and Sonalu (Cassia fistula), among other taxa. The understory includes Bambusa sp., Alsophila sp., and several ferns and epiphytes (Feeroz and Islam, 2000). There are 140 tree species, 19 mammal species, 19 reptile species, and four amphibian species (NSP, 2008).

\section{Project description}

The project, called the Bangladesh Climate Change Trust, was started in the Madhupur Sal forest area in June 2010 (FD, 2012). It was implemented with an integrated and holistic approach, under direct supervision of the local forest office of the Madhupur Forest Range. The project was initially launched for 3 years, but was extended for another 2 years, ending in June 2015.

The project has involved forest resource users, ethnic communities, Bengali communities and different organizations acting together to develop conservation and social development activities for sustainable forest management. The local forest office identified a total of 700 forestdependent individuals from the Madhupur forest area, and trained them in different income-generating initiatives. Among the participants, 500 illegal loggers were listed, according to the records of FD offenses, and another 200 poor forest dependents (income less than 1 US dollar/day/person) were selected for training. The participants received 2 months of intensive training. The training included growing trees in nurseries and reforestation, mushroom cultivation, medicinal plant cultivation, fisheries, poultry rearing, cattle fattening, apiculture, pisiculture, vegetable gardening, compost preparation, jam and jelly production, forest fire protection, and motivation to change attitudes. During the training period, every participant was given 4500 Taka (78 Taka $=1$ US dollar) per month as a training allowance. The trainers were also given uniforms, identity cards, and training materials. Trainers included public representatives, political leaders, journalists, government officials, NGO representatives, and academicians. After being trained, the participants were treated as CFWs, participating in the development of activities and helping the forest guard to protect the forests.

All CFWs received a 15-day refresher training organized by the FD 3 months after the main training. Every CFW received 800 Taka per month as a wage after the training. Each forest range office was responsible for monitoring the activities of the CFWs. Under each range, there was a representative committee of $\mathrm{CFWs}$ nominated by the general CFWs. All CFWs met monthly in the Madhupur forest office.

In addition, another 5500 families dependent on the forest were selected. These families, together with $700 \mathrm{CFWs}$, 
received incentives totaling 11,000 Taka. The families planted 200 saplings, including 50 fruit trees, 50 timber trees, and 100 fuel wood species, to gradually reduce dependence on forests and secure their livelihoods. The project also rejuvenated forests that were disturbed and/or depleted by other locals. During the project period, 1000 ha of degraded forest was replanted, mostly with native tree species in different forest beats.

Questionnaire and data collection

This study used the descriptive research design whereby a survey was conducted to assess the perceptions of people towards community development and forest conservation. A survey was conducted during January and February 2016 among the CFWs of the forestry project. Both quantitative and qualitative data were collected from primary and secondary data sources. Primary data was gathered using structured questionnaire while secondary data was sourced from books, reports and other published and unpublished sources. The literature from secondary data sources was used either to authenticate or support findings of this study.

The questionnaire was prepared in English and translated into the Bangla language. It was designed to gather information based on socioeconomic, demographic, cultural variables, and attitude regarding forest conservation. The questionnaire was administered to a small number of people ( $15 \%$ of total participants) before the final survey was done. The pilot survey was important to this study because it assisted in checking the reliability of information that was going to be gathered. We got similar results when repeated our questionnaire soon after the pilot.

The sample population was selected from 12 villages in the area, consisting of 186 males and 14 females of various ages (20-75 years old). The participants responded to the questionnaire with the help of other family members, as necessary. In addition to the questionnaire, informal meetings were held in each household. A focus group discussion was arranged in each village to gain a more complete understanding of community perceptions and to cross-check the validity of the data recorded during the interviews. The flow chart in Fig. 3 represents the overall study process used in our research.

\section{Livelihood analyses}

Livelihoods were viewed in a sustainable livelihood framework, to analyze and understand the complexity of rural development and its balance with forest conservation. We explored human, physical, financial, natural, and social livelihood capitals. Quantitative data were analyzed using SPSS 15.

\section{RESULTS}

\section{Demographic characteristics}

The characteristics of participants are listed in Table 1. Briefly, the average age of respondents was 44 years, and most were middle-aged. There were similar numbers of

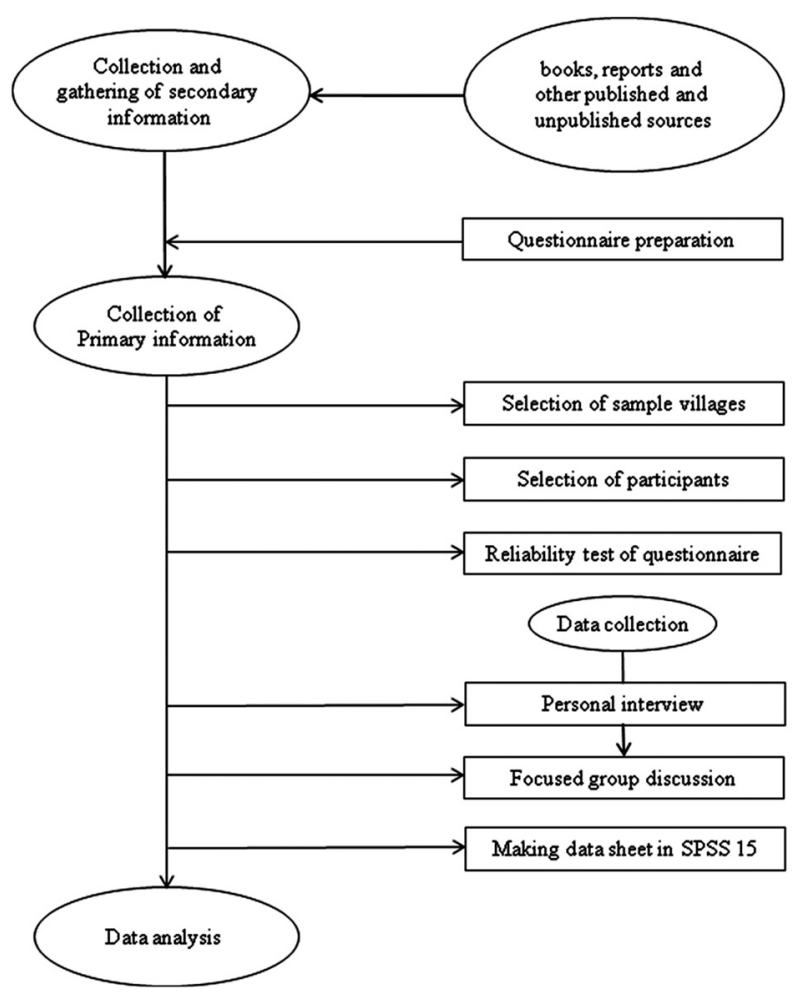

Fig. 3 The flow chart represents the overall study process used in our research.

ethnic and non-ethnic respondents, and $97.5 \%$ of participants were married. The literacy rate was $51 \%$. The average family size was 4.64, slightly above the national average of 4.50 (BBS, 2011). The average farm size was 0.59 ha, lower than the national average of 0.67 ha (Krishi Dairy, 2012). The religion of all ethnic respondents was Christianity, whereas the majority of non-ethnic respondents (97\%) were Islamic. Before the forestry program was started, the main source of income was illegal tree harvesting (80.5\%); after the program, the major occupation was farming $(65 \%)$.

\section{Livelihood capital}

We assessed multiple forms of livelihood capital, as detailed below.

\section{Human capital}

Human capital represents the skills, knowledge, health, and ability to pursue different livelihood strategies and achieve objectives (Roberts and Yang, 2003). To enhance knowledge and skills related to community development and forest management, the FD conducted 2 months of intensive training (requiring 15\% of the project budget) (FD, 2012). Such training can improve human capital, leading to improved household income (Islam et al., 2010). To understand the skills and improvement of the areas of the training program, we evaluated participant's skills according to five areas of training programs. We found that $96 \%$ of the participants able to explain in the area of vegetable gardening training program, compared to $85 \%, 83 \%, 78 \%$, and $74 \%$ in areas of nursery raising, Cattle fattening, Compost preparation, and Poultry rearing, respectively (Table 2). The training programs helped to build strong networks, enabling 
Table 1 Demographic characteristics of participants

\begin{tabular}{|c|c|c|}
\hline Variables & Frequency & Percentages (\%) \\
\hline \multicolumn{3}{|l|}{ Sex } \\
\hline Male & 184 & 92 \\
\hline Female & 16 & 8 \\
\hline \multicolumn{3}{|l|}{ Ethnicity } \\
\hline Banglee (Non ethnic) & 114 & 57 \\
\hline Garo (Ethnic) & 86 & 43 \\
\hline \multicolumn{3}{|l|}{ Age (Year) } \\
\hline (Young age) up to 30 & 70 & 35 \\
\hline (Middle age) $31-50$ & 89 & 44.5 \\
\hline (Old age) $>50$ & 41 & 20.5 \\
\hline \multicolumn{3}{|l|}{ Marital status } \\
\hline Married & 195 & 97.5 \\
\hline Unmarried & 3 & 1.5 \\
\hline Widow & 1 & 0.5 \\
\hline Widower & 1 & 0.5 \\
\hline \multicolumn{3}{|l|}{ Distribution of respondents by religion } \\
\hline Muslim & 112 & 56 \\
\hline Hindu & 3 & 1.5 \\
\hline Christian & 85 & 42.5 \\
\hline \multicolumn{3}{|l|}{ Family Size (Member) } \\
\hline Small $(<5)$ & 77 & 38.5 \\
\hline Medium $(6-8)$ & 106 & 53 \\
\hline Large $(>8)$ & 17 & 8.5 \\
\hline \multicolumn{3}{|l|}{ Education } \\
\hline Illiterate (No schooling) & 98 & 49 \\
\hline Primary $(1-5)$ & 57 & 28.5 \\
\hline Secondary $(6-10)$ & 35 & 17.5 \\
\hline Higher secondary (college and university) & 10 & 5 \\
\hline \multicolumn{3}{|l|}{ Farm size (Hectare) } \\
\hline Landless $(<0.02)$ & 8 & 4 \\
\hline Marginal (0.02-0.2) & 79 & 39.5 \\
\hline Small $(0.2-1)$ & 94 & 47 \\
\hline Medium (1-3) & 17 & 8.5 \\
\hline Large (>3) & - & - \\
\hline
\end{tabular}

Table 2 Participants' performance in major training programs

\begin{tabular}{llcc}
\hline \multicolumn{1}{c}{ Areas of Training } & \multicolumn{1}{c}{ Key objectives } & $\begin{array}{c}\text { Participant capable of } \\
\text { explanation (\%) }\end{array}$ & Skill evaluation \\
& & 85 & Very good \\
Nursery raising & Nursery establishment, raise income & 96 & Excellent \\
Vegetable gardening & Meet household demands, additional income & 78 & Good \\
Compost preparation & Improve soil health, additional income & 74 & Good \\
Poultry rearing & Improve nutrition, raise income & 83 & Very good \\
Cattle fattening & fast income & & \\
\hline
\end{tabular}

participants to work together as a team. In addition, illiterate participants were given more attention during the training sessions. After the training, 15 days of refresher courses were arranged for all of the participants. All participants reported enhanced skills after the program.

\section{Physical capital}

Physical capital comprises the basic infrastructure and goods required to support a livelihood (Jonathan, 2000). All project participants received incentive money to improve house and developed their household with guidance from project staff (Table 3).

Housing is obviously an important family asset. Prior to the project, participants owned mud houses with tin roofing $(75 \%)$, houses with bamboo-matt walls and tin or straw roofs $(22 \%)$, or brick houses with tin roofs (3\%). After the program, the proportions of each type of housing were $77 \%, 18.5 \%$, and $4.5 \%$, respectively. Houses consisted of 3-4 rooms, compared to $2-3$ rooms before the project. In addition, $47.5 \%$ of participants had tube wells and $36 \%$ had toilets before the project, whereas $98.5 \%$ and $87.5 \%$, respectively, had these basic utilities after the program.

Prior to the project, most participants (91.5\%) possessed various livestock, including cows, buffalos, goats, pigs, chickens, and ducks. Every participant bought a cow, goat, or pig after receiving the project incentive of Taka 5000. Approximately $75 \%$ of the participants raised poultry (chicken and duck) after the project, which was 13\% higher than prior to the project. Participants also tended to raise more cows but fewer goats, pigs, and buffalos after the project.

Use of expensive appliances (e.g., TV, CD player, motor 
bike, power tiller, irrigation pump) increased among the participants after joining the program. Moreover, $32 \%$ and $35 \%$ of the participants used solar panel power and electricity respectively, whereas only $12 \%$ of the participants used electricity before the program.

Table 3 Incentives provided by the project to locals

\begin{tabular}{ll}
\hline \multicolumn{1}{c}{ Taka } & \multicolumn{1}{c}{ Purpose } \\
(73 Taka= 1 U.S. dollar) & \multicolumn{1}{c}{ Improve homes } \\
\hline 3000.0 & Purchase a ruminant (e.g., cow, goat, pig) \\
5000.0 & To plant 200 seedlings on land \\
1000.0 & Vegetable cultivation \\
1000.0 & Compost preparation \\
1000.0 & Eco-friendly burner (one per family) \\
Free & \\
Total = 11000.00 Taka & \\
\hline
\end{tabular}

Source: BFD (1016)

Natural capital

Natural capital is the term used for natural resource stocks from which resource flow and services that are useful for livelihoods are derived (Goldman, 2000). Land is an important natural capital. The land provided by the FD for community forestry was not included in the measurement of each participant's holdings. The majority of respondents were marginal $(44.7 \%)$ to small farm holders $(47 \%)$. There were no large farm holders (Table 2).

The land provided for community forestry (mentioned above) was a 1 ha plot given to each participant and on which they were allowed to practice agro-forestry by planting local timber, fuel wood, fodder, and fruit species. Agro-forestry systems offer multiple alternatives and opportunities for farmers, with a view to improve farm production and income, and also provide productive and protective functions for the ecosystems (Sharma et al., 2007). Moreover, participants planted about 1,100,000 tree species (fruit, timber, and firewood species) on homestead premises.

Most participants $(65 \%)$ who engaged in agriculture reported that they planted high-yielding crops. Only a few $(8.5 \%)$ of the households reported collecting non-wood forest products (NWFPs) from the forest to supplement their livelihoods. The intensity of NWFP collection was highest among very poor people living in the forest.

Finally, 96\% of informants reported that they had stopped illegal cutting after the program. Changes in energy use, shifting from forest products to alternative fuel sources, were reported by $91.5 \%$ of the participants. More specifically, all of the participants started using improved stoves provided by the project, and $63 \%$ of the participants stated that the stoves saved $30-40 \%$ fuel compared to traditional stoves (Table 4).

Table 4 Fuel saved using improved stove

\begin{tabular}{ccc}
\hline Fuel saving & \multicolumn{2}{c}{ Participants' opinion } \\
\cline { 2 - 3 } category (\%) & Frequency & Percent (\%) \\
\hline $10-20$ & 15 & 7.5 \\
$21-30$ & 47 & 23.5 \\
$31-40$ & 57 & 28.5 \\
$41-50$ & 77 & 38.5 \\
$>50$ & 4 & 2 \\
\hline
\end{tabular}

Financial capital

Financial capital represents the monetary resources that people use to achieve livelihood objectives (Lasse, 2001). Financial capital includes two main sources: available stock (e.g., savings, cash, liquid assets) and regular flow of money (e.g., wages, pension, sale of agriculture products). A remarkable change in the respondents' primary means of securing a livelihood was noticed in the community. Before joining the project, illegal tree cutting was the primary source of income for $80.5 \%$ of the participants, followed by farming (10.5\%), and forest product collection (5.0\%). After initiating co-management activities, the majority of participants $(65 \%)$ reported farming (crop cultivation, vegetable gardening, fruit cultivation, etc.) as their primary source of income/livelihood (Table 5). Illegal cutting and selling of trees was another livelihood that almost stopped during the project period, being replaced with alternative livelihoods.

Table 5 Changes in occupations in the study area

\begin{tabular}{llc}
\hline Period & Occupations & $\begin{array}{c}\text { Relative } \\
\text { frequency (\%) }\end{array}$ \\
\hline Before joining & Illegal tree cutting & 80.5 \\
the project & Farming & 10.5 \\
& Forest product collection & 5.0 \\
& Day labor & 2.5 \\
& Others & 1.5 \\
After joining & Farming & 65.0 \\
the project & Day labor (agric. and non agric.) & 16.5 \\
& Small business & 7.0 \\
& Poultry rearing & 5.0 \\
& Livestock rearing & 3.5 \\
& Others & 3.0 \\
\hline
\end{tabular}

The project supplied wages to the participants to guard the forest and sale of trained participant's (16.5\%) labor to agriculture and commercial farms to sustain their livelihood. In some cases, such as family financial crisis, participants were forced to sell their trees, cattle, and goats for money. A remarkable number of participants $(71.5 \%)$ received loans from NGOs, relatives, neighbors, or local banks for crop cultivation, livestock rearing, small businesses, and other purposes. An increase in the average monthly income was observed in the community. The lowest-income group was reduced from $35.8 \%$ before the project to $19.4 \%$ after it (Fig. 4).

\section{Social capital}

There is much debate about what exactly is meant by the term social capital (DFID, 1999). Social capital refers to the social resources that people draw on to make a living, including relationships with more powerful people (vertical connections) and others such as themselves (horizontal connections), as well as memberships to groups or organizations. We analyzed relationships between participants and FD staff as well as the general community (Table 6). Among participants, $40.5 \%$ indicated that they felt that they had good relations with FD staff; only 1\% indicated that they did not. In addition, $48.5 \%$ and $54.0 \%$ of the participants felt that they received more respect after the program from $\mathrm{FD}$ staff and from their family members, respectively. About $49.5 \%$ of the participants reported that, since joining the 


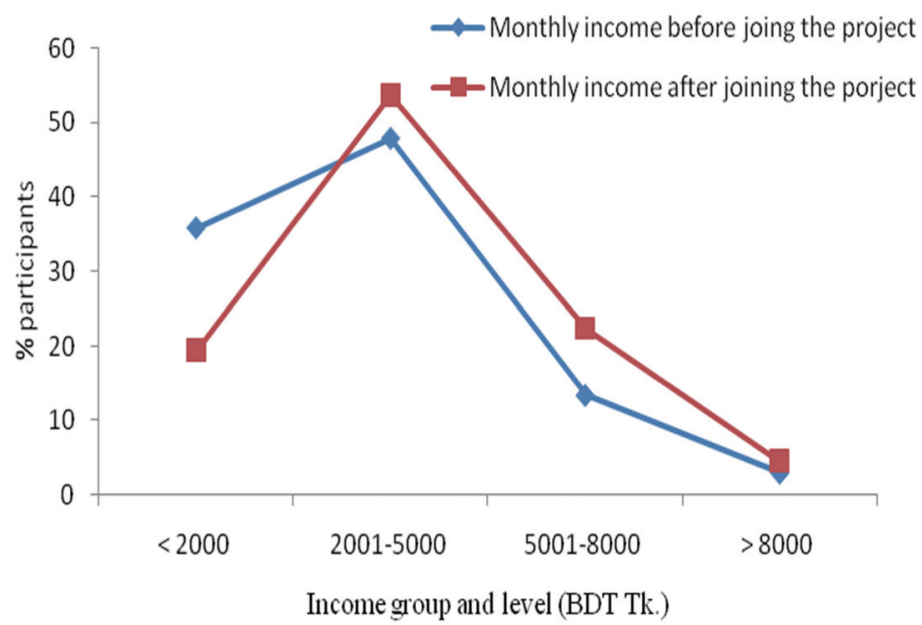

Fig. 4 Comparative monthly income of participants before and after joining the project

Table 6 Improved social parameters

\begin{tabular}{|c|c|c|c|c|c|}
\hline \multirow[b]{2}{*}{ Parameters } & \multicolumn{5}{|c|}{ Participants' opinions (\%) } \\
\hline & $\begin{array}{l}\text { Strongly } \\
\text { agree }\end{array}$ & Agree & Neutral & Disagree & $\begin{array}{l}\text { Strongly } \\
\text { disagree }\end{array}$ \\
\hline Do you feel that you have good relations with FD staff? & 40.5 & 37.5 & 11.5 & 9.5 & 1 \\
\hline Do you feel more respected by the FD staff? & 48.5 & 37.5 & 12 & 2 & - \\
\hline Do you feel more respected by family members? & 54 & 38 & 6 & 2 & - \\
\hline Do you get more invitations to social ceremonies? & 53.5 & 35 & 8 & 3.5 & - \\
\hline Do you get more help from neighbors in emergencies? & 49.5 & 32 & 15 & 2.5 & 1 \\
\hline Do you think that your skills have been developed? & 46.5 & 30.5 & 15 & 8 & - \\
\hline Do you make decisions in consultation with your spouse or other family members? & 36 & 42 & 15.5 & 6.5 & - \\
\hline
\end{tabular}

project, they received more invitations to social ceremonies such as weddings, religious activities, and other social events. The same percentage reported receiving more help from neighbors during emergencies.

Female participants were asked three specific questions: Has there been a reduction in discrimination by others when you go outside the home? Has there been a reduction in abuse by your husband? Has there been a reduction in demand for dowry by your husband or husband's family? A remarkable reduction was reported for all three situations.

Forest conservation

Forest conservation refers to the successful protection, improvement, and/or creation of specific forests and/or specific forest functions and services (Sunderlin et al., 2005). Forest conservation can provide the motivation to protect, improve, and/or create functions and services that benefit people living in or near a given forest or far from them.

The FD initiated a revegetation project as part of their program. The FD included 1000 ha of encroached forest land, to be planted with local tree species of timber, fruit, fodder, and so on (Table 7). The participants would received $45 \%$ of the income generated from the project for 10 years (the FD would also receive $45 \%$ and the remaining $10 \%$ would go toward future tree farm management funds). To reduce dependency on forests for fuel wood, timber, and other resources, the project supplied 200 tree species (e.g., timber, firewood and fruit species) to every participant and 5500 forest-dependent families. The study observed that about $52.5 \%$ trees have survived after 5 years in their homestead premises, when the participants started benefiting. Most of the participants collected firewood, either from their homestead or market, rather than from the forest.

The real causes of destruction of Madhupur forest have

Table 7 Revegetation scheme of the Madhupur Sal Forest

\begin{tabular}{|c|c|c|c|c|}
\hline Year & Tree type/use & Area (ha) & $\begin{array}{l}\text { No. of } \\
\text { Trees }\end{array}$ & Tree species \\
\hline \multirow[t]{2}{*}{$1^{\text {st }}$} & Native timber, fuel wood and fruit & 150 & 375000 & Blackberry (Sytzygium cumini), Bohera (Terminalia belerica), \\
\hline & Native fodder & 10 & 16000 & Chickrosi (Chukrassia tabularis), Dhakijam (Syzygium grande), Gamar \\
\hline $2^{\text {nd }}$ & Native timber, fuel wood and fruit & 600 & 1500000 & (Gmelina arborea), Garjan (Dipterocarpus turbinatus), Jackfruit \\
\hline $3^{\text {rd }}$ & Native timber, fuel wood and fruit & 250 & 625000 & (Artocarpus heterophyllus), Kadom (Neolamarckia cadamba), \\
\hline & Native fodder & 10 & 16000 & Mahogany (Swietenia macrophylla), Neem (Azadirachta indica), Sal \\
\hline $1^{\text {st }} \& 2^{\text {nd }}$ & Local fruit, timber and fuel wood & Homestead & 1100000 & (Shorea robusta), Star apple (Syzygium samarengense) \\
\hline
\end{tabular}

Source: BFD (1016) 
not been rightly diagnosed in the past. Only those who felled trees in the forest have been blamed for the forest destruction. The Madhupur forest office have been filed huge cases in court against the tree loggers. The new policy has been able to lessen the gap between local ethnic and non ethnic community and build up confidence. Positive attitude has been developed among people of Madhupur. As a result, forest offenses such as illegal logging, land encroachment and other illegal activities were gradually reduced during the project period. In 2008-2009 and 2009-2010, there were 361 and 376 offenses, respectively. In 2010-2011, there were only 23. There were no offenses in 2011-2012, 2012-2013, or 2013-
2014 (Fig. 5). Forest disturbances by anthropogenic activities had decreased due to decrease in forest offences, cattle grazing, and forest product collection. The absence of anthropogenic disturbances has had an important impact on the natural regeneration of the forest floor. A number of young tree species of timber, fruit, medicinal, shrub, climber etc. were found naturally regenerated in the forest floor opined by participants (Table 8 ). In addition, they also put their opinion about wildlife increases (Table 9). More than $50 \%$ participants were agreed with raises of deer, cock and monkey in compare with the period before program launched.

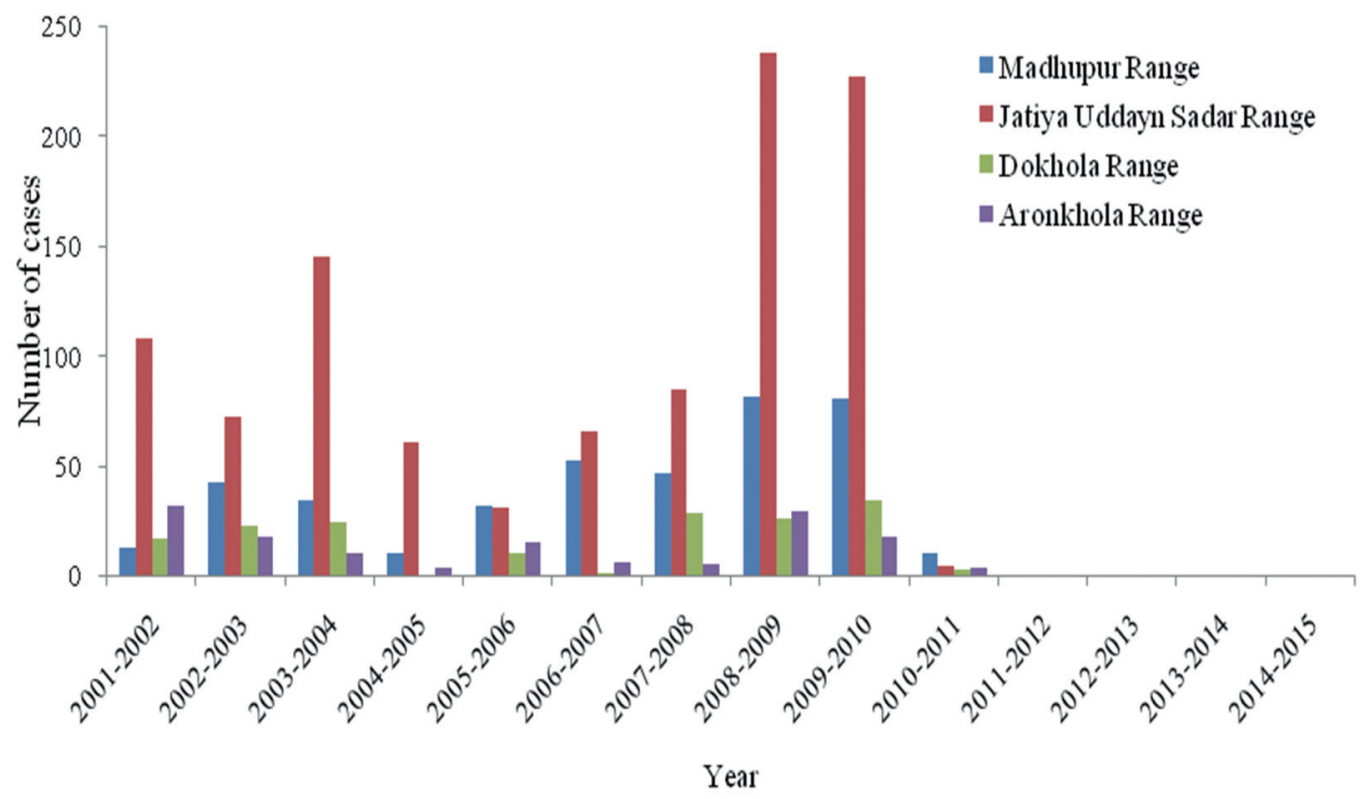

Fig. 5 Trend of offences in Madhupur Sal forest over time (Source: IUCN, 2014)

Table 8 Tree species naturally regenerated in forest floor opined by participants

\begin{tabular}{lcc}
\hline \multicolumn{1}{c}{ Unit } & Frequency & Percent (\%) \\
\hline Timber Trees & 98 & \\
Sal (Shorea robusta) & 78 & 39 \\
Gandhi gajari (Miliusa velutina) & 62 & 31 \\
Koroi (Albigia procera) & 42 & 21 \\
Ajuli (Dillenia pentagyna) & 29 & 14.5 \\
Shida (Lagerstroemia parvifloraRoxb) & 17 & 8.5 \\
Kaika (Adima cordifolia) & 16 & 8 \\
Shiris (Albiria sp.) & 15 & 7.5 \\
Segun (Tectona grandis) & 12 & 6 \\
Giza (Odina Older) & 34 & 17 \\
Others (Jarul, Arjun, Bot, Sonalu etc.) & & \\
Fruit trees & 143 & 71.5 \\
Black berry (Syzygium cumini) & 104 & 52 \\
Anaigota (Ziziphus rugosa) & 48 & 24 \\
Ban Alu (Dioscorea bulbifera) & 32 & 16 \\
Pahari banana (Musa textilis) & 27 & 13.5 \\
Neor (Bursera serrata) & 42 & 21 \\
Jaina (Schleichera oleosa) & & \\
Medicinal Plants & 108 & 54 \\
Amloki (Phyllanthus emblica) & 103 & 51.5 \\
Bohera (Tenninalia arjuna) & 53 & 26.5 \\
Haritaki (Terminalia belerica) & & \\
Undergrowth and climbers & 18 & 9 \\
Bet (Calamus spp.) & 15 & 7.5 \\
Monkata (Randia dumentorum) & & \\
\hline & &
\end{tabular}


Table 9 Increased wildlife's availability in the forest opined by respondents

\begin{tabular}{lcc}
\hline \multicolumn{1}{c}{ Unit } & Frequency & Percent (\%) \\
\hline Deer & 165 & 82.5 \\
Cock & 155 & 77.5 \\
Monkey & 116 & 58 \\
Birds & 96 & 48 \\
Mukhpora Hanuman & 51 & 25.1 \\
Pig & 42 & 21 \\
Snake & 38 & 17 \\
Cat & 29 & 14.5 \\
Porcupine & 27 & 13.5 \\
Fox & 23 & 11.5 \\
Rabbit & 21 & 10.5 \\
\hline
\end{tabular}

Finally, we asked participants about their willingness to extend the project. All respondents expressed a firm intention to continue with the project. When asked why, most cited economic benefits and protection of the forest, and very few did not respond.

\section{DISCUSSION}

The present study attempted to highlight protecting forests, sharing resource management and ensuring secure livelihoods for those dependent on forest through a forestry project. Participation in this project "Revegetation of Madhupur Forest through Rehabilitation of Forest-Dependent Local and Ethnic Communities," had a positive influence on livelihood development and forestry management. The development program was built around a vision for human empowerment, advancement, and welfare, with the fullest range of available natural resources being available (Mbie et al., 2005). Our results revealed the existence of strong relationships among FD staff and participants, despite the fact that most participants were illegal loggers before the project was initiated.

The participants knew each other quite well and a strong, collaborative attitude was built among them. Previously, most of the participants were dependent on the forest for their livelihoods. They earned subsistence money, either by engaging in illegal logging activities or collecting forest products, thus accelerating forest degradation. After starting the project, however, they stopped stealing timber from the forests and became crop producers or engaged in other income-generating activities.

The success of the FD program involved people radically departing from their roles of tree destroyers to forest protectors. They benefited from their participation in the project, which discouraged them from further involvement in activities destructive to the forest and encouraged them to engage in the conservation process. The intensive training and motivation, as well as the monetary incentives, changed the attitudes of the community.

Ezebilo (2011) reported that local people residing in the vicinity of the Cross River National Park in Nigeria highly preferred collaborative management of local resources that combined biodiversity, conservation, and community development. Islam et al. (2013) reported that a rehabilitation project for Sal forest dependents in Bangladesh resulted in a high participation rate among encroachers and forest dependents, resulting in capacity building, social relationship development, and the use of natural assets and human capital through alternative livelihood strategies that have provided security and improved livelihoods. According to Yadav et al. (2003), natural resources in most regions of Nepal deteriorated before the introduction of community forestry, but the forests improved where community forestry was well-established.

In the present study, we also observed some shortcomings of the project. For example, the FD made most decisions regarding project implementation; hence, while participants were empowered by the project they were not in control of most aspects. We also found that while participants protected the forest, some owners of saw mill and brick field tried to influence them to cut trees illegally. Finally, after the project concluded, and wages and incentives from the FD were terminated, the participants again considered pursuing illegal logging.

\section{Improved human capital}

The development of human capital improved the capability of individuals to secure their well-being. In this study, human capital included training, as well as refresher courses. Specialized training was also built on awareness of these issues in the community. Training could enhance skills, which might have a significant impact on the participants' attitudes, as well as on forest conservation (Islam et al., 2012). In this study, participants were highly inspired in response to the training program that focused on conserving Sal forest. Moreover, acquired skills and knowledge affect social capital, such as building relationships and encouraging selfsufficiency within participating groups.

An important finding from this study was the change in attitude of the FD staff toward the participants and local people. Muhammad et al. (2008) claimed that, as for the implementing agency of any project, the staff included in his study played a role in the failure of the project. They did not seek active participation of genuinely poor people and other direct stakeholders in the forestry projects. Tole (2010) also mentioned that state officials entrusted with the design and implementation of co-management projects in many developing countries often have negative attitudes about community empowerment, which impedes the full realization of the project goals. This did not occur in our study.

\section{Improved physical capital}

Most participants improved their houses after being involved in the project. In a case study in Bangladesh, Islam and Sato (2012) found a similar trend for non-ethnic groups but ethnic participants showed negative attitudes after being involved in a participatory forestry program.

Animal husbandry is an important livelihood activity in the study area. Animals are reared for milk, manure, meat, and farming activities. All of the participants were given a ruminant from the project, but in general the average number of livestock decreased due to a lack of grazing land and shortage of fodder in the study area. A similar trend was 
reported by Islam and Sato (2012).

The participants had previously allowed open grazing of their livestock in the forest. After the project, open grazing was restricted and human entrance as well. Good communication and transportation is a prerequisite for community development. However, improvements to roads and other public goods were beyond the scope of this project. We did find that access to and use of some expensive appliances such as televisions, CD players, and solar panels increased among the participants after the project.

Improved natural capital

Natural capital was one of the main income sources for participants. Most participants produced crops that generated income. Moreover, agro-forestry practices in the participatory forestry plots provided additional income. Muhammad et al. (2008) also identified agro-forestry as being the most beneficial practice among different land-use patterns for public-oriented forestry in the Tangail Forest Division of Bangladesh.

Participants used their financial capital to cover household expenses and partially sustain their livelihoods. Livelihoods and natural resources are closely interrelated, where the decline of one puts additional pressure on the other (Rigg, 2006). Community forests are natural capital Access to forest resources, particularly firewood, was restricted. In the study area, wood was the main energy source for cooking. Before the project, the majority of participants were dependent on forests as a source of firewood. The project helped to minimize their firewood demand, by establishing homestead forestry, but some of the local poor people still depend on the forests for this resource.

\section{Improved financial capital}

Financial assets denote disposable income from various sources. Adequate financial resources help to overcome external risks. The major source of cash income of the participants was associated with farming. The trained participants worked on farms, which provided a good source of seasonal income. The participants received wages from the project as well, which provided regular income. Moreover, loans from different sources were obtained to support their livelihoods.

Participants spent their money on household items, appliances, and agricultural inputs. Some also invested in education and health care for their children. Hence, the extra financial capital helped to partially sustain their livelihoods. In the event of family crises, the sale of natural resources such as trees and livestock generated enough to meet their emergency financial needs. Therefore, the project helped to boost their financial capital, but their livelihoods depended on all types of capital.

\section{Improved social capital}

Social capital plays an important role in the management of natural resources and improvement of livelihoods, particularly in remote, rural areas (Nath and Inoue, 2010). The benefits of the creation of social capital depend on the participation of households and individuals in local institutions and enhanced knowledge of rights and duties involved in securing a livelihood. Knowledge, skills, and motivation have a strong impact on social capital, which builds positive relationships and capabilities.

In our study, intensive training and CFW activities helped to create good social networks. Participants developed social relationships among themselves and with the project staff and neighbors. In the past, locals had not been satisfied with the FD or their own community. These relationships improved throughout the project. Muhammad et al. (2008) reported similar results.

The project also improved most participants' satisfaction with their annual diet, clothing, health care, education, and entertainment (Table 8).

Progress related to women's rights were also improved. In rural Bangladesh, women are usually deprived of their status and respect, both in the family and in society (Subhani, 2008), although it is generally recognized that women play an important role in resource management because of their knowledge, skills, and experience. In this study, officials encouraged women to actively participate in the project activities and this reduced mental and physical harassment and also improved their empowerment both in the family and in society. Subhani (2008) also reported improvements in skills, knowledge, decision-making power, and respect in females who participated in co-management projects in Lawachara National Park, Bangladesh.

\section{Improved forest condition}

The project reduced dependency on forest resources and thus improved the preservation of biodiversity and the socioeconomic development of the local communities. The community-based projects improved the living conditions of local residents, alleviated pressures on resources, and reduced conflicts between community members and forest managers (Blaint, 2006).

Sawhney et al. (2007) reported that participation in such projects improves when adequate incentives are offered and the roles of participants are clearly defined. The Sal project achieved these objectives, and both the community and the forest benefited.

Table 10 Improvements in household expenditures

\begin{tabular}{|c|c|c|c|c|c|c|c|c|}
\hline \multirow{3}{*}{ Unit } & \multicolumn{8}{|c|}{ Participants' opinions (\%) } \\
\hline & \multicolumn{4}{|c|}{ Before joining the project } & \multicolumn{4}{|c|}{ After joining of the project } \\
\hline & Highly satisfied & Satisfied & Less satisfied & Not satisfied & Highly satisfied & Satisfied & Less satisfied & Not satisfied \\
\hline Food & - & 34.3 & 65.7 & - & 11.9 & 83.6 & 4.5 & - \\
\hline Cloths & 1.5 & 26.9 & 58.2 & 13.4 & 14.9 & 62.7 & 22.4 & - \\
\hline Health & - & 13.4 & 79.1 & 7.5 & 11.9 & 71.6 & 16.4 & - \\
\hline Education & 3 & 12.1 & 80.3 & 4.5 & 16.7 & 72.7 & 10.6 & - \\
\hline Amusement & - & 7.6 & 59.1 & 33.3 & 9.1 & 36.4 & 42.4 & 12.1 \\
\hline
\end{tabular}


More specifically, incentives for livelihood improvement and inspirational development of various socio-cultural parameters of the community were the basis for sound forest management. The participants became highly motivated during training and were committed to conserving the forest. This was achieved through protection (patrolling by CFWs) of forests from illegal tree felling, livestock grazing outside of the forest, and a reduction in the extraction of forest products. These reductions in external pressures probably keep the forest undisturbed and promoted the natural regeneration of the forest floor, which increased canopy cover. The natural regeneration of vegetation is a dynamic process by which life recolonises land when the vegetation has been partially or totally destroyed. Life recovers the lost ground through the mechanism of the succession of species. The most evident way to restore vegetative cover is to protect it from the causes for degradation mostly exploitation which can spread naturally, but the process is often slow. The species were naturally regenerated because seeds were fallen from surrounding trees to forest floor of stumped sprouts and root suckers developed from them, but it is necessary to understand the strategy for survival of each tree species. Jayakumar and Nair (2013) reported that tree regeneration was higher in species rich vegetation type with no sign of human disturbances in Tropical Forests of the Western Ghats, India. Putul et al. (2003) reported about 55, 68 and $52 \%$ species were found to be regenerating in the undisturbed, mildly disturbed, moderately disturbed stand, and there were no species found in highly disturbed stands in tropical wet evergreen forest in Arunachal Pradesh, Eastern Himalayas, India. They also stated that variation in species richness, distribution pattern and regeneration potential is related to human interference and the need for forest conservation is emphasized. On the other hand, the vegetation is providing important resources for nesting, food and protection for a variety of wildlife, resulting, and their increases in the forest. Saara et al. (2003) reported that changes in tropical forest structure and species composition that occur during regeneration following land abandonment may have important consequences for wildlife populations.

In addition, the participants attempted to resuscitate degraded forest lands. Plantations can play an important role in biodiversity conservation and restoration of forest species, particularly when management aims to balance environmental and economic goals (Hartley, 2002; Brockerhoff et al., 2008). Leah and Kathleen (2010) suggested that plantations are most likely to contribute to biodiversity when established on degraded lands rather than replacing natural ecosystems, such as forests, grasslands, and shrublands, and when indigenous tree species are used rather than exotic species. The plots given out for planting trees adjacent to the Madhupur Sal forest may eventually become a part of the natural forest canopy, increasing overall tree cover. Faruq et al. (2016) reported an increase in natural forest cover of Madhupur Sal forests in Bangladesh. Zaman and Katoh (2011) found significant increases in forest cover in areas protected by local governments and private owners. They also observed conversion of some croplands into closed and opened forest tracts in the Thakurgaon Forest in northern
Bangladesh. Islam et al. (2013) reported that re-vegetation activities have proceeded in Sal forest area of Bangladesh, even as authorities ignore many of the illegal activities of forest-dependent people. The net effect is that there has been a significant improvement in the vegetation.

In our study, at the start of the program, participants who were most dependent on the forest were in conflict with the program, particularly in the initial stages. Firewood sellers, in particular, complained bitterly about the restrictions on collecting firewood, although their firewood needs were still accommodated, at least to some extent. They were also encouraged to pursue other alternative incomegenerating activities, including farming, nursery production, and the rearing of livestock and poultry. These alternatives eventually contributed considerably to their family incomes and also reduced their dependency on forest for resource collection. Mukul and Quazi (2008) also reported a collaborative management project that combined biodiversity conservation and community development and the project almost eliminated illegal logging and the use of forest trees for firewood. Shubani (2008) also reported that a majority of female members involved in a similar project in Satchari National Park, Bangladesh abandoned firewood collection to become involved in more sustainable activities.

For people dependent on forests, it is difficult to reduce the collection of forest trees for firewood, especially for cooking. Thus, in the study area, to reduce dependence on the forest for timber and firewood, all participants were provided different tree species to cultivate in their homestead premises and in plots given to them for this purpose. The participants were also given improved cooking stoves to save firewood and they were experienced to save fuel using the stove. IAP (2008) reported that a one mouth portable improved cocking stove can save $50 \%$ of fuel and $25 \%$ more effective compare with a traditional mud stove.

\section{CONCLUSION}

In this study, co-management of a Sal forest in Bangladesh greatly improved the livelihoods of the people dependent on the forest and enhanced the forest's conservation. Recognizing the interrelationships between community livelihoods and forest resource conservation, the rehabilitation project involved both the local community and local government officials. This project might be a model for Bangladesh's forestry sector.

The results of this study have potential implications for the broader context of co-management in Bangladesh and other developing countries. Among other factors, social capital played an important role in achieving project objectives. The project developed good relationships between local communities and the FD.

The program enhanced various types of livelihood capital, and improved access to livelihood opportunities. The project properly addressed community needs and problems, and developed capacity building through intensive training and by providing alternatives for new occupations. The project reduced illegal logging and encouraged the planting 
of native species by project participants. Therefore, attempts to conserve the Sal forest were successful.

To prevent further destruction of this forest, and further develop the livelihoods of those who depend it, the FD should consider continued conservation and livelihood strategies for locals; the forest should be protected through coordination among the FD, police, and the justice department; and all brick fields and sawmills in the forest area should be monitored and their owners strongly motivated to not use Sal timber illegally.

\section{ACKNOWLEDGEMENTS}

The authors are grateful to the Madhupur Sal forest office staff for their assistance and active support during the survey and information collection. We would like to thank the members of the Forest Measurement and Planning Laboratory, Shinshu University, for their advice and assistance with the study. We also express our heartfelt gratitude to Mr. Richard Turner, Textcheck (http://www. textcheck.com/certificate/ZcmpC9) for his assistance in improving the language of the draft manuscript.

\section{LITERATURE CITED}

Ahmed, A.I.M.U. (2008) Underlying causes of deforestation and forest degradation in Bangladesh. Global forest coalition (GFC), Netherlands. Available from: http://www. globalforestcoalition.org (accessed on January 10, 2015)

Alam, M., Furukawa, Y., Sarkar, S.K. and Ahmed, R. (2008) Sustainability of Sal (Shorea robusta) forest in Bangladesh: past, present and future actions. Int. Forestry Rev. 10: 29-37

BBS (2011) Bangladesh Bureau of Statistics. Statistical Yearbook of Bangladesh. Ministry of Planning, Government of the people's Republic of Bangladesh. Available from: http://www.bbs.gov.bd/ (accessed on April 20, 2015)

BFD (2004) Participatory Forestry Newsletter. Bulletin 3, December 2004. Bangladesh Forestry Department, Government of the People's Republic of Bangladesh. (accessed on June 20, 2016)

BFD (2011) Forest Type: Tropical Moist Deciduous Forests. Bangladesh Forestry Department, Government of the People's Republic of Bangladesh. Available from: http:// bforest. gov. bd / index-category / tropical-moist-dediduousforest (accessed on June 20, 2016)

BFD (2016) Bangladesh Forest Department. Land and forest area of Bangladesh. Available from: https://www.bforest. gov.bd (accessed on April 5, 2016)

Blaint, P.J. (2006) Improving community based conservation near protected areas: the importance of development variables. Environ. Manage. 38: 137-148

Brockerhoff, E.G., Jactel, H., Parrotta, J.A., Quine, C.P. and Sayer, J. (2008) Plantation forests and biodiversity: oxymoron or opportunity? Biodivers Conserv. 17: 925-951

DFID (1999) Sustainable Livelihoods Guidance Sheets. Department for International Development, London. Available from: http://www.eldis.org/vfile/upload/1/ document/ 0901/section2.pdf (Accessed on June 14, 2016)

Ezebilo, E.E. (2011) Local participation in forest and biodiversity conservation in a Nigerian rain forest. Int. J. Sust. Dev. World Ecol. 18: 42-47

Faruq, M.A.A., Zaman, S. and Katoh, M. (2016) Analysis of Forest Cover Changes Using Landsat Satellite Imagery: A Case Study of the Madhupur Sal Forest in Bangladesh. J. For. Plann. 21: 29-38

Feeroz, M.M. and Islam, M.A. (2000) Primates of West Bhanugach Forest Reserve: major threats and management plan. In: Ahmed, M. F. (eds) Bangladesh Environment 2000. BAPA Bangladesh Poribesh Andolon, Maulvibazar. 239-253 pp

GOB (2010) Forest department official website. Government of the People's Republic of Bangladesh. Available from: http//www.bforest.gov.bd/land.php (accessed on October 20, 2015)

Goldman, I. (2000) Sustainable Livelihoods Approaches: Progress and Possibilities for Change. Available from: http: //www.eldis.org/vfile/upload/1/document/0812/ LA_ Progress.pdf. (accessed on April 20, 2016)

Hartley, M.J. (2002) Rationale and methods for conserving biodiversity in plantation forests. For. Ecol. Manage. 155: 81-95

IAP (2008) Addressing Indoor Air Pollution. Technical Manual of Improved Cooking Stoves. Available from: http: www. Renewable \% 20 energy $\% 20$ practices $\% 20$ in $\% 20$ Bangladesh\% 20cook\%20stoves.pdf, (Access on. 21 June, 2016.)

Iftekhar, M.S. (2006) Forestry in Bangladesh, an Overview. J. Forest. 104: 148-153

Islam, K.K. and Sato, N. (2012) Participatory forestry in Bangladesh: has it helped to increase the livelihoods of Sal forests dependent people. J. Forest Sci. 74: 89-101

Islam, K.K., Rahman, G.M., Fujiwara, T. and Sato, N. (2013) People's participation in forest conservation and livelihoods improvement: experience from a forestry project in Bangladesh. Int. J. Biodiver. Sci. 9: 30-43

Islam, K.K., Sato, N. and Hoogstra, M. (2010) Poverty alleviation in Bangladesh: the case of the participatory agroforestry program. Int. Forestry Rev. 12: 412-415

IUCN (2014) The IUCN red list of threatened species. International Union for Conservation of Nature. Bangladesh Country office. Available from: https://books. google.co.jp/books?isbn=9843383648 (accessed on May 10, 2016)

Jayakumar, R. and Nair, K.K.N. (2013) Species Diversity and Tree Regeneration Patterns in Tropical Forests of the Western Ghats, India. Journal of ISRN (International Scholarly Research Network) ecology, Vol. 2013, Article ID 890862

Jonathan, G. (2000) Sustainable livelihoods. Int. Social Sci. J. 17: $77-86$

Kamiowitz, D. and Angelsen, A. (1998) Economic models of tropical deforestation a review. Center for International Forestry Research, Bogor, Indonesia. 153pp

Krishi Dairy (2012) Agricultural information Service, Ministry of Agriculture, Government of the People's Republic of Bangladesh. 
Landell-Mills, N. and Porras, T.I. (2002) Silver bullet or fools' gold? A global review of markets for forest environmental services and their impact on the poor. Instruments for sustainable private sector forestry series. International Institute for Environment and Development, London. 249pp

Lasse, K. (2001) The Sustainable Livelihood Approach to Poverty Reduction. International Development Cooperation Agency, Sweden. Available from: http://www. forestry. umn.edu/prod/groups/cfans/@pub/@cfans/@forestry / documents/asset/cfans_asset_202603.pdf. (accessed on May 14, 2016)

Leah, L.B. and Kathleen, A.F. (2010) Does plantation forestry restore biodiversity or create green deserts? A synthesis of the effects of land-use transitions on plant species richness. Biodivers Conserv. 19: 3893-3915

Mbie, P., Vabi, M., Meboka, M., Okon, D., Arrey-Mbo, J., Nkongho, F. and Ebong, E. (2005) Linking management and lihelihood in environmental conservation: case of the Korup National Park Cameroon. J. Environ. Manage. 76: 1-13

McNeely, J.A. (1990) The future of national parks. Environment: Sci. Pol. Sustain. Dev. 32: 16-20

Muhammed, N., Koike, M., Hauqe, F. and Miah, M.D. (2008) Quantitative assessment of people-oriented forestry in Bangladesh: a case study in the Tangail forest division. J. Environ. Manage. 88: 83-92

Mukul, S.A. and Quazi, S.A. (2008) Communities in conservation: protected area management and enhanced conservation in Bangladesh. In: Robin N. Leslie (eds) The future of Forests in Asia and the Pacific: Outlook for 2020, Edition: RAP Publication: 2008/03. Publisher: Food and Agriculture Organization, Regional Office for Asia and the Pacific, p. 143-159

Nath, T.K. and Inoue, M. (2008) How does local governance affect project outcomes? Experience from a participatory forestry project in Bangladesh. Int. J. Agric. Resour. Governance Ecol. 7: 491-506

Nath, T.K. and Inoue, M. (2010) Impacts of participatory forestry on livelihoods of ethnic people: experience from Bangladesh. Soc. Nat. Resour. 23: 1093-1107

NSP (2008) Framework management plan for Madhupur National Park, Nishorgo Support project, Bangladesh. Available from: http//www.nishorgo.org/ nishorgo2/pdf/ reports/GENERAL\%20REPORTS/1.MNP_Framework_ ManagementPlan/ (accessed on May 15, 2016)

Panta, M., Kim, K. and Joshi, C. (2008) Temporal mapping of deforestation and forest degradation I Nepal: Applications to forest conservation. Forest Eco. Manage. 256: 1587-1595

Pelletier, J., Kirby, K.R. and Potvin, C. (2010) Significance of carbon stock uncertainties on emission reductions from deforestation and forest degradation in developing countries. Forest Pol. Econ. 12: 497-504

Putul, B., Khan, M.L. and Tripathi, R.S. (2003) Tree diversity and population structure in undisturbed and humanimpacted stands of tropical wet evergreen forest in Arunachal Pradesh, Eastern Himalayas, India. Biodiversity Conser. 12: 1753-1773.
Rahman, M.M. (2003) Sal forest. In: Islam, S., Miah, S. (eds.) Banglapedia: National Encyclopedia of Bangladesh. Asiatic Soc. Bangladesh, Dhaka. 9: 28-29

Rigg, J.K. (2006) Forests, marketization, livelihoods and the poor in the Lao RDR. Land Degra. Dev. 17: 123-133

Roberts, M.G. and Yang, G.A. (2003) The international progress of sustainable development research: A comparison of vulnerability analysis and the sustainable livelihoods approach. Adv. Earth Sci. 22: 11-21

Saara, J.D., Satya, K.M. and Julie, S.D. (2003) Changes in vegetation structure and composition along a tropical forest chronosequence: implications for wildlife. Forest Ecol. Manage. 182: 139-151

Sawhney, P., Kobayashi, M., Takahashi, M., King, P.N. and Mori, H. (2007) Participation of civil society in management of natural resources. Int. Rev. Environ. Strategies. 7: 117-132

Shackleton, C.M., Shackleton, S.E., Buiten, E. and Bird, N. (2007) The importance of dry woodlands and forests in rural livelihoods and poverty alleviation in South Africa. Forest Pol. Econ. 9: 558-577

Sharma, R., Xu, J. and Sharma, G. (2007) Traditional agroforestry in the eastern Himalayan region: Land management system supporting ecosystem services. Int. Society Trop. Econ. 48: 189-200

Subhani, R. (2008) Impacts of co-management activities on women members of forest user group in Satchari National Park. In: fox, j., Bushley, B.R., Dutt. S., Quazi, S.A. (eds) Connecting communities and conservation: collaborative management of protected areas in Bangladesh. United States Agency for International Development (USAID). P. 231-250

Sunderlin, W.D., Anglsen, A., Belcher, B., Burgers, P., Nasi, R., Santos, L. and Wunder, S. (2005) Livelihoods, forests and conservation in developing countries: an overview. World Dev. 33: 1383-1402

Tole, L. (2010) Reforms from the ground up: a review of community based forest management in tropical developing countries. Environ. Manage. 45: 1312-1331

Turyahabwe, N., Agea, J.G., Tweheyo, M. and Tumwebaze, S. B. (2012) Collaborative Forest Management in Uganda: Benefits, Implementation Challenges and Future Directions. Sustainable Forest Management - Case Studies, Dr. Julio J. Diez (Ed.), ISBN: 978-953-51-0511-4, InTech, Available from: http : / / www. intechopen. com / books / sustainable-forestmanagement-case-studies/collaborativeforest-managementin-uganda-benefits-implementation-challenges-and-futuredirections. (accessed on March 10, 2016)

Yadav, N.P., Dev, O.P., Springate-Baginski, O. and Soussan, J. (2003) Forst management and utilization under community forestry. J. For. Livelihood. 3: 37-50

Zaman, S. and Katoh, M. (2011) Assessment of forest covers change in tropical moist deciduous forest in Thakurgaon, Bangladesh using ALOS data. J. For. Plann. 16: 285-292

(Received 23 August 2016) (Accepted 11 January 2017) 